\title{
Integrasi, Interkoneksi "Keislaman, Kebangsaan dan Nahdlatul Wathan" Perspektif Historis dari Nahdlatul Wathan untuk Indonesia.
}

\author{
Wandi \\ STIES Syari'ah Al Mujaddid Tanjung Jabung Timur \\ Email: huseinwandi220@gmail.com \\ M. Arif Musthofa \\ STIE Syari'ah Al-Mujaddid Tanjung Jabung Timur \\ Email: 7ariefherio@gmail.com \\ Zaenal Abidin \\ STIE Syari'ah Al-Mujaddid Tanjung Jabung Timur \\ Email: zaabiangsui@gmail.com
}

\begin{abstract}
Abstrac
This research is motivated by an interesting discourse related to Integration, Interconnection "Islam, Nationality and Nahdlatul Wathan" Historical Perspective, because it sees this organization as a large organization in Indonesia, from the breakthroughs of this organization it is also appropriate to study in terms of its contribution in the field of education. social, religious and cultural. This type of research in this study is a literature study by collecting related books about the Nahdlatul Wathan organizational movement, or research subjects related to Nahdlatul Wathan equipped with social change theory according to Max Weber. The result is that one of the causes of the establishment of the Nahdlatul Wathan Organization is that one of them is to unite Muslims in eastern Indonesia and even Muslims in Indonesia in the spirit of a better direction especially in the field of education, with the idea that was born a container of Islamic religious organizations that has main activities in the field of education, social and Islamic da'wah. This organization was founded by Mr. Guru KH. Muhammad Zainuddin Abdul Madjid on March 1, 1953. Since its establishment in 1953, of course there have been many contributions from the Nadhlatul Wathan Organization to Islam, this nation.
\end{abstract}

Keywords: Integration, Interconnection "Islam, Nationality and Nahdlatul Wathan"

\begin{abstract}
Abstrak
Penelitian ini dilatarbelakangi oleh sebuah diskursus yang menarik terkait Integrasi, Interkoneksi "Keislaman, Kebangsaan dan Nahdlatul Wathan" Perspektif Historis, karena melihat Organisasi ini termasuk Organisasi yang besar di Indonesia, dari gebrakan-gebrakan Organisasi ini patut juga kiranya untuk dikaji dari segi kontribusinya dibidang pendidikan, sosial keagamaan dan budaya. Jenis penelitian
\end{abstract}

Nur El-Islam, Volume 6, Nomor 2, Oktober 2019 
Integrasi, Interkoneksi "Keislaman ...

pada studi ini adalah studi pustaka dengan mengumpulkan buku-buku terkait mengenai gerakan organisasi Nahdlatul Wathan, ataupun subjek-subjek penelitian yang terkait dengan Nahdlatul Wathan dilengkapi dengan teori perubahan sosial menurut Max Weber. Hasilnya adalah diantara salah satu penyebab berdirinya Organisasi Nahdlatul Wathan adalah salah satunya adalah untuk mempersatukan umat Islam di wilayah timur Indonesia bahkan umat Islam di Indonesia dalam bingkai semangat ke arah yang lebih baik khususnya dalam bidang pendidikan, dengan gagasan itu lahir sebuah wadah organisasi keagamaan Islam yang memiliki kegiatan utama dalam bidang pendidikan, sosial dan dakwah Islamiah. Organisasi ini didirikan oleh Tuan Guru KH. Muhammad Zainuddin Abdul Madjid pada tanggal 1 Maret 1953. Sejak berdiri tahun 1953 tentunya sudah banyak sekali kontribusi Organisasi Nadhlatul Wathan untuk Islam, bangsa ini.

Kata Kunci: Integrasi, Interkoneksi “Keislaman, Kebangsaan dan Nahdlatul Wathan”

\section{A. Latar Belakang}

Organisasi masyarakat dan wajah Indonesia tidak akan pernah bisa dilepaskan dari peran pemimpin-pemimpinnya pada saat itu. Terbukti setelah kemerdekaan banyak capaian-capaian gemilang dan membanggakan umat Islam untuk mempertahankan kemerdekaan dan kemajuan bangsa Indonesia, bahkan tidak heran jika sampai sekarang ini relasi antara ormas Islam dan Indonesia begitu intim dan tidak dapat dipisahkan seperti yang akan penulis bahas dalam tulisan dibawah ini.

Organisasi Nahdlatul Wathan adalah organisasi keagamaan Islam yang memiliki kegiatan utama dalam bidang pendidikan, sosial dan dakwah Islamiah. Organisasi ini didirikan oleh Tuan Guru KH. Muhammad Zainuddin Abdul Madjid pada tanggal 1 Maret 1953. Sejak berdiri tahun 1953 tentunya sudah banyak sekali kontribusi Organisasi Nadhlatul Wathan untuk Islam, bangsa ini.

Pendirian organisasi Nahdlatul Wathan dilatarbelakangi oleh kebutuhan akan adanya suatu badan yang dapat berfungsi sebagai koordinator, pembimbing dan pengayom dari kegiatan Madrasah Nahdlatul Wathan Diniyah Islamiyah, dan Madrasah Nahdlatul Banat Diniyah Islamiyah yang telah berkembang pesat dengan banyaknya cabang-cabang kedua Madrasah itu, NWDI dan NBDI kini telah di integrasikan menjadi Pondok Pesantren Darun Nahdlatain NW 
(PPDNW) Pancor yang menjadi induk Madrasah Nahdlatu Wathan yang tersebar di wilayah nusantara. ${ }^{1}$

Melihat sepak terjang Organisasi Nahdlatul Wathan penulis jadi tertarik untuk menulis tentang Integrasi, Interkoneksi "Keislaman, Kebangsaan dan Nahdlatul Wathan" Perspektif, Historis dari Nahdlatul Wathan untuk Indonesia. Organisasi dan lembaga pendidikan yang di gagas oleh Nahdlatul Wathan sudah membawa dampak perubahan corak positif untuk Indonesia, serta mewujudkan tujuan kehidupan berbangsa dan bernegara sebagaimana termaktub dalam pembukaan UUD 1945, “yaitu mercerdaskan kesidupan berbangsa”.

Terkait alasan mengapa penulis mengambil tema Integrasi, Interkoneksi "Keislaman, Kebangsaan dan Nahdlatul Wathan" Perspektif, Historis dari Nahdlatul Wathan untuk Indonesia. Penulis ingin melihat dari kacamata sejarah bagaimana perjuangan Nahdlatul Wathan ikut serta dan mempunyai andil besar buat kemajuan bangsa Indonesia, penulis juga ingin melihat bagaimana Integrasi ketiga term ini, yang menurut penulis sangat berkaitan jika ingin mengakaji Nadhlatul Wathan secara empiris khususnya sumbangsih Nahdlatul Wathan untuk Indonesia.

\section{B. Metode Penelitian}

Karya ini ditulis berdasarkan studi literatur dan interpretasi secara mendalam serta akumulasi pemahaman dari berbagai sumber buku-buku primer terpercaya yang menulis tentang studi-studi pokok gerakan Nahdlatul Wathan. Studi literatur berasal dari hasil penelitian terdahulu, dan buku-buku terpercaya dan telah dijadikan sebagai acuan utama untuk memahami konsep tentang. Integrasi, Interkoneksi "Keislaman, Kebangsaan dan Nahdlatul Wathan" Perspektif Historis, dari Nahdlatul Wathan untuk Indonesia. Pengumpulan data dilakukan melalui metode tinjaun pustaka terhadap buku-buku karangan tentang gerakan ormas tersebut.

${ }^{1}$ Abdul Hayyi, Maulana Syaikh TG. KH. Muhammad Zainuddin Abdul Madjid, Biografi dan Perjuangannya, (NTB, PBNW, 2003). 


\section{Landasan Teori}

Sebenarnya dalam kajian ormas seperti Nahdlatul Wathan dapat saja diambil berbagai teori, tetapi disini penulis ingin mengkaji ormas ini dalam perspektif perubahan sosial menurut Max Weber yang mana ia mengatakan bahwa perubahan situasi dalam masyarakat sebagai akibat adanya ketidaksesuaian unsur-unsur. Hampir sama dengan topik diatas salah satu alasan berdirinya ormas Nahdlatul Wathan adalah untuk memajukan pendidikan, sosial keagamaan dan budaya di kawasan timur Indonesia dan Islam di Indonesia secara luas, perubahan secara mendasar dari kebodohan dan kemerotan akhlaq ke arah yang lebih baik melalui gerakan pendidikan, sosial keagamaan dan budaya.

\section{Pembahasan}

\section{Sejarah Beridirinya Nahdlatul Wathan.}

Nahdlah dan al wathan, Nahdlah berarti kebangkitan pergerakan, pembangunan, al Wathan berarti tanah air atau negara, jadi Nahdlatul Wathan adalah kebangkitan tanah air, pembangunan negara atau membangun negara, secara terminologis Nahdlatul Wathan adalah organisasi Islam Ahlussunnah waljama'ah. ${ }^{2}$ Pendirian organisasi Nahdlatul Wathan dilatarbelakangi oleh kebutuhan akan adanya suatu badan yang dapat berfungsi sebagai koordinator, pembimbing dan pengayom dari kegiatan Madrasah Nahdlatul Wathan Diniyah Islamiyah, dan Madrasah Nahdlatul Banat Diniyah Islamiyah yang telah berkembang pesat dengan banyaknya cabang-cabang kedua Madrasah itu, NWDI dan NBDI kini telah diintegrasikan menjadi Pondok Pesantren Darun Nahdlatain NW (PPDNW) Pancor yang menjadi induk Madrasah Nahdlatu Wathan yang tersebar di wilayah nusantara. ${ }^{3}$

${ }^{2}$ Ma'shum Ahmad Abdul Madjid, “Meneladani Kepemimpinan Hamzanwadi”, Makalah disampaikan pada acara Kongress HIMMAH NW V di Pancor pada tanggal 14 Mei 1994.

${ }^{3}$ Hayyi, Maulana Syaikh TG. KH. Muhammad. 
NWDI adalah lembaga pendidikan agama bagi kaum pria yang didirikan pada tanggal 17 Agustus 1936 di Pancor Lombok Timur, Nusa Tenggara Barat. Madrasah NWDI secara resmi dibuka pada tanggal 22 Agustus 1937 bertepatan dengan tanggal 15 Jumaddil Akhir 1356 Hijriah. Sedangkan NBDI adalah lembaga pendidikan agama bagi kaum perempuan yang didirikan pada tanggal 21 April 1943 bertepatan dengan 15 Rabiul Akhir 1362 Hijriah.

Perjuangan Nahdlatul Wathan yang dimulai sejak kelahiran Madrasah NWDI bisa dikatakan matang, dari tahun ke tahun terus mengalami dinamika dan perubahan, adapun perubahan penting yang dialami organisasi Nahdlatul Wathan adalah berkembangnya peran dan fungsi NW sebagai organisasi kemasyarakatan yang menjalankan aktivitas dalam bidang penguatan masyarakat sipil (civil society), oleh karena itu Nahdlatul Wathan sekarang dikenal organisasi keagamaan dan kemasyarakatan. Sumbangsih Nahdlatul Wathan untuk masyarakat Indonesia memiliki peran yang sangat besar khususnya masyarakat Nusa Tenggara Barat, dimana pendidikan sebagai gerakan sangatlah perlu untuk sekarang dan yang akan datang, yang mana saat itu Nahdlatul Wathan sudah mencetuskannya. ${ }^{4}$

Kesadaran Nahdlatul Wathan tentang pentingnya pendidikan untuk masyarakat pada saat itu patut diapresiasi baik untuk organisasi maupun pencetus tokohnya yaitu Tuan Guru KH. Muhammad Zainuddin Abdul Madjid, oleh jasa-jasanya telah lahir organisasi Nahdlatul Wathan dan melalui moment ini kita memperingati hari jadi ke dua Majlis Dakwah Hamzawadi II semoga keberkahan selalu tercurahkan kepada para auliya-auliya ini. Perlu juga diketahui organisasi Nahdlatul Wathan sangat berperan dalam pengembangan pendidikan Islam di Nusantara Barat, selain itu organisasi ini juga berfokus pada bidang sosial dan dakwah Islamiah.

Visi dan misi yang dilakukan Nahdlatul Wathan seperti yang penulis sebut diatas adalah, tidak hanya terfokus pada pendidikan, tetapi juga bergerak dibidang sosial dan dakwah Islamiyah, yang pada saat itu dilakukan ditempat-tempat sederhana dan sekarang fasilitas

${ }^{4}$ Madjid, “Meneladani Kepemimpinan Hamzanwadi”, h. 307. 
Integrasi, Interkoneksi "Keislaman ...

itu sedikit-demi sedikit dapat memenhi kebutuhan para pelajar dengan dibangunnya pondok pesantren dan berbagai fasilitas didalamnya. Organisasi ini tampil sebagai solusi masyarakat Islam pada saat itu, dengan visi misi yang jelas memiliki AD/ART agar Nahdlatu Wathan dapat ikut serta memberi sumbangsih untuk perkembangan Indonesia yang lebih baik. ${ }^{5}$

\section{Konsistensi Nahdlatul Wathan untuk Indonesia}

Organisasi kemasyarakatan yang tumbuh dan berkembang di Indonesia eksistensinya diakui oleh konstitusi. Pengakuan tersebut harus tetap dipertahankan oleh setiap organisasi kemasyarakatan dengan mengkuti ketentuan-ketentuan konstitusi dan peraturan perundang-undangan yang berlaku di Negara Kesatuan Republik Indonesia. ${ }^{6}$

Nahdlatul Wathan sebagai organisasi kemasyarakatan yang bergerak dalam bidang pendidikan, sosial, dan dakwah Islamiyah dan beraqidahkan Islam ahlusunnah wal jama'ah ala madzhab imam syafi'I terus dan tetap eksis di bumi pancasila ini. Hal menunjukkan bahwa Nahdlatul Wathan sebagai organisasi Islam yang selalu memperjuangkan tegaknya aqidah ahlulsunnah wal jama'ah diterima oleh masyarakat Islam negeri ini yang mayoritas bermazhab Syafi'i.

Keuletan dan ketekunan pendiri Nahdlatul Wathan, Tuan Guru KH. Muhammad Zainuddin Abdul Madjid serta bantuan kader Nahdlatul Wathan yang telah tersebar dalam menyampaikan dakwah dan misi Nahdlatul Wathan menjadikan organisasi ini terkenal dan menjadi panutan masyarakat. Nahdlatul Wathan dalam melaksanakan aktivitas organisasi berdasarkan pada:

1. Akte Nomor: 48 tahun 1957 yang dibuat dan disahkan oleh Notaris Pembantu Hendrik Alexander Malada di Mataram.

${ }^{5}$ Muhammad Nur, dkk, Visi Kebangsaan Religius: Refleksi Pemikiran dan Perjuangan Tuan Guru Kyai Haji Muhammad Zainuddin Abdul Madjid 1904-1997, (Jakarta: Logos Wacana Ilmu, 2004), cet. 1.

${ }^{6}$ Abdul Hayyi Nu'man \& Sahafari As'ary, Organisasi Nahdlatul Wathan Di Bidang Pendidikan, Sosial dan Dakwah Islamiyah, (Pancor: Toko Buku Kita, 1984), cet.1. 
2. Akte Nomor: 50 tanggal 25 juli 1960 yang disahkan oleh Notaris Pengganti Sie Ik Tiong di Jakarta, dengan pengakuan dan penetapan Menteri Kehakiman pada tanggal 17 Oktober 1960, Nomor: J.A 5/105/5 dan dimuat dalam Berita Negara Republik Indonesia Nomor : 90 tanggal 8 November 1960.

3. Akte nomor: 31 tanggal 15 Februari 1897 dan Akte Nomor: 32 tanggal 15 Februari 1987 yang dimuat dan disahkan oleh wakil notaries sementara Abdurahman SH. ${ }^{7}$

Akta-akta tersebut merupakan landasan hukum organisasi Nahdlatul Wathan dalam melaksanakan aktivitas diseluruh wilayah Negara Kesatuan Republik Indonesia, dan jika kita dari legalitas Nahdlatul Wathan patut kiranya mengakui bahwa antara azaz Islam, Bangsa dan Nahdlatul Wathan saling berintegrasi dan berkoneksi demi satu tujuan kearah Indonesia yang lebih baik lagi.

Organisasi Nadlatul Wathan sesuai dengan misinya yaitu pendidikan, sosial dan dakwah Islamiyah sudah mengahantarkan Indonesia kedepan pintu germbang kemerdekaan dalam artian merdeka dalam berfikir, bersosial dan bebas untuk menyampaikan dakwah-dakwah Islamiyah yang berlandaskan ajaran Ahlul sunnah waljamaah serta tidak bertentangan dengan UUD dan Pancasila. Dimana dahulu sejak masa penjajahan kita semua tahu bahwa gerakan-gerakan masyarakat Indonesia yang mengarah pada kemerdekaan itu sangat ditentang oleh Kolonial. Namun setelah merdeka Nahdlatul Wathan dan masyarakat Indonesia bersatu saling mengisi demi Negara Indonesia yang lebih baik. ${ }^{8}$

\section{Integrasi, Interkoneksi "Keislaman, Kebangsaan dan Nahdlatul Wathan".}

Integrasi-Interkoneksi adalah pengertian umum tentang penggabungan beberapa hal, dalam hal ini penulis ingin menyorot tentang paradigma keislamanan, kebangsaan dan Nahdlatul Wathan

\footnotetext{
${ }^{7}$ Organisasi Nahdlatul Wathan, diakses pada tanggal 20 November 2018.

${ }^{8}$ Baharuddin, Nahdltul Wathan dan Perubahan Sosial, (Yogyakarta: Genta Press, 2007), cet. 1, h. 227.
} 
dimana menurut penulis Nahdlatul Wathan sesuai visi dan misinya dapat memberikan kontribusi untuk bangsa khususnya warga Nusa Tenggara Barat. Faham tentang Islam, bangsa, dan Nahdlatul Wathan secara terpadu dan menyeluruh merupakan suatu konsep menarik yang dibangun oleh Tuan Guru KH. Muhammad Zainuddin Abdul Madjid pada saat itu. ${ }^{9}$

\section{a. Aqidah, Asas, Tujuan dan Ruang Lingkup Usaha}

Nahdlatul Wathan menganut aqidah Islam Ahlussunnah wal jama'ah ala mazhab imam Syafi'i, dan berdasarkan Pancasila sesuai dengan tuntutan Undang-undang Nomor 8 Tahun 1985. Sedangkan tujuan organisasi Nahdlatul Wathan adalah li'ila kalimatil wa' izzul Islam wal muslimin dan keselamatan serta kebahagian hidup didunia dan akhirat. Dalam upaya mencapai tujuan organisasi, telah diterapkan ruang lingkup usaha organisasi Nahdlatul Wathan seperti termuat dalam Anggaran Dasar, yaitu:

1. Menyelenggarakan pendidikan dan pengajaran melalui pokok pesantren, diniyah, madrasah/sekolah dari tingkat taman kanakkanak sampai perguruan tinggi, kursus-kursus, serta meningkatkan dan menyempurnakan pendidikan, pengajaran, dan kebudayaan.

2. Menyelenggarakan kegiatan sosial seperti menyelenggarakan panti asuhan keluarga,rubath/pondok/asrama pelajar/mahasiswa, Pos kesehatan, Pondok Pesantren, Balai pengobatan, Balai Kesehatan Ibu dan Anak, Klinik Keluarga Sejarhtera dan Rumah Sakit.

3. Menyelenggarakan dakwah Islamiyah melalui pengajian (majlis dakwah/majlis taklim) tablig, penerbitan, mengembangkan pusat informasi pondok pesantren, dan media lainnya.

4. Menyelenggarakan usaha-usaha lain yang tidak bertentangan dengan ajaran Islam dan tidak merugikan Nahdlatul Wathan dengan mengindahkan ketentuan perundang-undangan yang berlaku dalam Negara Kesatuan Republik Indonesia. ${ }^{10}$

\footnotetext{
${ }^{9}$ Nur, Visi Kebangsaan Religius, h. 10.

${ }^{10}$ Organisasi Nahdlatul Wathan, diakses pada tanggal 20 November 2018.
} 
Terkait akidah, azaz, tujuan dan ruang lingkup usaha yang digagas oleh Nahdlatul Wathan dan jika kita kaji secara empris, gebrekan-gebrekan seperti ini sangat positif untuk pembangunan dan kemajuan bangsa khususnya masyarakat Nusa Tenggara Barat dan Indonesia, terkhusus dalam bidang pendidikan, seperti pesantren, diniyah, madrasah sampai ke perguruan tinggi, selain itu juga ada kegiatan sosial, kegiatan dakwah Islamiyah. Apabila di Integrasi dan Interkoneksikan Keislaman, Kebangsaan dan Nahdlatul Wathan, layak kiranya kita menyebut bahwa organisasi Nahdlatul Wathan sebagai bagian tubuh penting untuk Indonesia.

b. Nahdlatul Wathan dari gerakan Islam sampai ke Pendidikan untuk Indonesia.

1) Organisasi Nahdlatul Wathan menganut faham ahlulssunnah waljamaa'ah hal ini ditegaskan dalam Anggaran Dasar Nahdlatul Wathan, juga dalam Hizib Nahdlatul Wathan susunan pendiri Nahdlatul Wathan Tuan Guru KH. Muhammad Zainuddin Abdul Madjid. Ajaran ini pada dasanya dapat dibagi dalam tiga bidang yaitu aqidah, syari'ah, dan tasawuf. Bidang aqidah menyangkut masalah keimanan, dibahas dalam ilmu tauhid. Bidang syari'ah menyangkut bidang hukum Islam yang berkaitan dengan perbuatan manusia, meliputi ibadah, muamalah, munakahat, dan jinayat, hal ini dibahas dalam ilmu fiqih. Sedangkan bidang tasawuf yang menyangkut masalah bertalian dengan akhlak dan budi pekerti, bertalian dengan hati, yaitu cara-cara ikhlas, khusyu, tawadhu, muraqabah, mujahadah, sabar, ridho, tawakkal dan lainlain, hal ini dibahas dalam ilmu tasawuf.

2) Organisasi kemasyarakatan yang kegiatannya dipusatkan dalam bidang pendidikan, sosial, dan dakwah merupakan patner pemerintah dalam upaya membangun manusia seutuhnya dan membangun seluruh masyarakat Indonesia yang mayoritas beragama Islam dalam rangka mewujudkan tujuan nasional sebagaimana tercantum dalam pembukaan UUD 1945.

Nahdlatul Wathan sebagai organisasi kemasyarakatan Islam telah memberikan andil kepada agama, nusa dan bangsa, dibawah ini 
akan dikemukakan perkembangan Nahdlatul Wathan dalam bidang pendidikan dan perannya membantu pemerintah mencerdaskan bangsa. Kebutuhan serta hajat masyarakat yang semakin besar dalam bidang pendidikan, tampaknya merupakan salah satu pendorong bagi Nahdlatul Wathan untuk berupaya meningkatkan dan mengembang diri dalam mengelola pendidikan. Pertumbuhan dan perkembangan pondok pesantren, madrasah, dan sekolah di lingkungan Nahdlatul Wathan terus mengalami peningkatan, baik jumlah dan jenis sekolah dan madrasah, tingkat atau jenjang pendidikannya, maupun kurikulum yang digunakan terutama yang berada di kelompok NWDI dan NBDI di Pancor. ${ }^{11}$

\section{c. Dinamika Pendidikan Nahdlatul Wathan Perspektif Historis}

Berdasarkan dari data yang penulis dapat Organisasi Nahdlatul Wathan, baik dari referensi buku maupun artikel dari Internet Pada tahun pelajaran 1955an dibuka Madrasah Muballighin/Muballighat sebagai tempat membina kader-kader penerus perjuangan Nahdlatul Wathan tetapi hanya berjalan 2 tahun. Pada hari sabtu tanggal 22 juni 1957 Mua'limin dan mu'alimat 4 tahun dijadikan 6 tahun yakni NWDI dan NBDI 6 tahun dengan memakai bahasa arab aktif pada pelajaran agama dari kelas II. Pada tahun 1959 diresmikan berdirinya, Madrasah Menengah Atas (MMA), sebagai lanjutan dari Tsanawiyah dan Mu'allimin dan 4 tahun kemudian pada 15 Jumaddil Akhir $1380 \mathrm{H} \mathrm{(3}$ Desember 1960) status NWDI dan NBDI 6 tahun dijelmakan menjadi Mua'limin dan mu'alimat 6 tahun. Pada 6 Syawal 1383 H (20 Februari 1964) PGAP dijadikan PGAL (Pendidikan Guru Agama Lengkap), dan Tsanawiyah 4 tahun menjadi 6 tahun dan MMA menjadi Madrasah Menengah atas 3 tahun. Pada tahun 1974 didirikan SMP,SMA dan sebuah kejuruan yaitu SPG. ${ }^{12}$

${ }^{11}$ Fahrurrozi, Eksistensi Pondok Pesantren di Lombok NTB: Studi Tentang Peranan Pondok Pesantren Nahdlatul Wathan dalam bidang Pendidikan, Sosial dan Dakwah, (Jakarta: PPS UIN Jakarta, 2004), h. 3.

${ }^{12}$ Organisasi Nahdlatul Wathan, diakses pada tanggal 20 November 2018. 
Di Madrasah-madrasah lanjutan atas tersebut persentase pelajaran agama berbeda-berbeda. Di Mu'allimin dan Mu'allimat pelajaran agama 50\% dan pelajaran umum $50 \%$ di Tsanawiyah 6 tahun pelajaran agama $70 \%$ dan pelajaran umum $30 \%$ di MMA pelajaran agama 90\% dan pelajaran umum 10\%. Adapun PGAL mengikuti kurikulum PGAL Negeri. Pendidikan sekolah-sekolah umum di lingkungan Nahdlatul Wathan menurut Tuan Guru KH. Muhammad Zainuddin Abdul Madjid adalah untuk membentengi madrasahmadrasah (umat) yang terjaga dari tipu daya. ${ }^{13}$

Perkembangan lembaga-lembaga pendidikan di lingkungan Nahdlatul Wathan dari tahun ketahun menunjukkan kemajuan, tidak hanya ditingkat menengah tetapi juga ditingkat perguruan tinggi. Hal ini sebagai pertanda bahwa hajat masyarakat akan pendidikan semakin besar. Pada tahun 1964 didirikan Akademi Paedagogik Nahdlatul Wathan. Akademi ini berjalan beberapa tahun diPancor, kemudian tidak lama sesudah dipindahkan ke Mataram. Akademi ini tidak mengadakan kegiatan lagi. Pada tahun 1965 dibuka perguruan tinggi Ma'had Darul Qur'an Wal Hadis Al-Majidiyyah As-Syafi'iyyah Nahdaltul Wathan yang mahasiswanya khusus pria dan Ma'had lil Banat khusus untuk wanita dibuka pada tahun 1974. Perguruan tinggi tersebut mengunakan kurikulum 100\% agama. Pada tahun 1977 didirikan Universitas HAMZANWADI. HAMZANWADI adalah singkatan dari Haji Muhammad Zainudinh Abdul Madjid Nahdlatul Wathan Diniyaah Islamiyah. Universitas HAMZANWADI ini pada awalnya membuka dua fakultas, yaitu Fakultas Tarbiyah dan Ilmu Pendidikan dan sampai sekarang Universitas ini berkembang dengan lumayan pesat. ${ }^{14}$

Dalam rangka pengembangan perguruan tinggi di lingkungan Nahdlatul Wathan pada tahun akademik pengembangan perguruan tinggi di lingkungan Nahdlatul Wathan pada tahun akademik

${ }^{13}$ Muhammad Zainuddin Abdul Majid, Hizib Nahdlatul Wathan wa hizib Nahdlatul Banat, (Pancor: Toko Buku Kita, 1984) cet.ke-74, h. 70.

${ }^{14}$ Fahrurozi, Eksistensi Pondok Pesantren di NTB, dalam jurnal Pesantren Studies, (Jakarta: Depag RI, 2008), h. 5. 
1987/1988 didirikan Universitas Nahdlatul Wathan yang berkedudukan di Mataram ibukota Provinsi Nusa Tenggara Barat. Untuk tahap pertama dibuka empat fakultas, yaitu Fakultas Teknologi Pertanian, Fakultas Perkebunan, Faklutas Ketatanegaraan, dan Fakultas Ketataniagaan (FKK), dan Fakultas Sastra Arab (Arab, Inggris, Indonesia). Pada tahap selanjutnya fakultas-fakultas tersebut berubah menjadi Fakultas Pertanian, Fakultas Matematika dan Ilmu Pengetahuan Alam (FMIPA), Fakultas Ilmu Administrasi (FIA), dan Fakultas Sastra. ${ }^{15}$

Satu hal yang perlu diketahui ciri khas pendidikan dilingkungan Nahdlatul Wathan pada masa sekarang ini, disamping menggunakan kurikulum pemerintah (Departemen Agama dan Departemen Pendidikan dan Kebudayaan) juga ditambah dengan pengetahuan agama yang bersumber pada kitab-kitab karangan Ulama Ahlulssunnah wal Jama'ah mengaktualisasikan Anggaran Dasar Nahdlatul Wathan yang menyatakan bahwa Nahdlatul Wathan menganut aqidah Ahlulssunnah waljamaah ala mazhab Syafi'I. demikian juga mata pelajaran dan mata kuliah ke-NWan diberikan sebagai mata kuliah atau mata kuliah wajib disemua lembaga pendidikan Nahdlatul Wathan. Selain itu masih ada beberapa gerakan Nahdlatul Wathan untuk Indonesia diantarannya bidang sosial, keagamaan dan dakwah. ${ }^{16}$

\section{E. Kesimpulan}

Akhirnya penulis berakhir pada kesimpulan bahwa, Integrasi, Interkoneksi “Keislaman, Kebangsaan dan Nahdlatul Wathan”. Sangat berdampak bagi masyarakat khususnya warga Nahdlatul Wathan dan masyarakat Indonesia pada umumnya. Kita bersuyukur bahwa pada zaman dahulu lahir seorang kyai besar yang diplopori oleh Tuan Guru KH. Muhammad Zainuddin Abdul Madjid yang mendirikan organisasi Nahdlatul Wathan pada tanggal 1 Maret 1953. yang kita sangat

\footnotetext{
${ }^{15}$ Organisasi Nahdlatul Wathan, diakses pada tanggal 20 November 2018.

${ }^{16}$ Ahmad Amir Aziz, Pemikiran Dan Pola Dakwah TGKH. M.Zaenuddin Abdul Majid, (Laporan Penelitian,1999), h. 86.
} 
rasakan betapa besar sumbangsihnya buat rakyat dan bangsa yang kita cintai ini.

\section{Daftar Pustaka}

Abdul Hayyi Nu'man \& Sahafari As'ary, Organisasi Nahdlatul Wathan Di Bidang Pendidikan, Sosial dan Dakwah Islamiyah, (Pancor: Toko Buku Kita)1984, cet.1.

Abdul Majid Muhammad Zainuddin, Hizib Nahdlatul Wathan wa hizib Nahdlatul Banat, Pancor: Toko Buku Kita, cet.ke-74

Aziz Ahmad, Pemikiran Dan Pola Dakwah TGKH. M.Zaenuddin Abdul Majid, Laporan Penelitian,1999.

Baharuddin, Nahdltul Wathan dan Perubahan Sosial, (Yogyakarta: Genta Press, 2007), cet. 1.

Fahrurrozi, Eksistensi Pondok Pesantren di Lombok NTB: Studi Tentang Peranan Pondok Pesantren Nahdlatul Wathan dalam bidang Pendidikan, Sosial dan Dakwah, (Jakarta: PPS UIN Jakarta,2004).

-Eksistensi Pondok Pesantren di NTB, dalam jurnal Pesantren Studies, (Jakarta: Depag RI, 2008).

Abdul Hayyi, Maulana Syaikh TG. KH. Muhammad Zainuddin Abdul Madjid, Biografi dan Perjuangannya, (NTB, PBNW, 2003),

Ma'shum Ahmad Abdul Madjid, BA, “Meneladani Kepemimpinan Hamzanwadi", Makalah disampaikan pada acara Kongress HIMMAH NW V di Pancor pada tanggal 14 Mei 1994.

Muhammad Nur, dkk, Visi Kebangsaan Religius: Refleksi Pemikiran dan Perjuangan Tuan Guru Kyai Haji Muhammad Zainuddin Abdul Madjid 1904-1997, Jakarta: Logos Wacana Ilmu, 2004, cet. 1.

Organisasi Nahdlatul Wathan, diakses pada tanggal 20 November 2018. 